\title{
Common Issues in High School Student's Career Decision - Making Choice and Supporting Measurement in Career Consulting
}

\author{
Truong Thi Hoa* \\ Faculty of Psychology and Pedagogy, Hanoi National University of Education, Hanoi, Vietnam \\ *Corresponding author: hoatlgd.dhsphn@gmail.com
}

Received January 14, 2018; Revised April 10, 2018; Accepted April 15, 2018

\begin{abstract}
This study has been conducted on 2131 students of 8 (eight) high schools in urban area and outskirts in Hanoi on the majors, careers decision-making choice of students in the career decision-making process. Survey results show that students have not fully and accurately evaluated their own characteristics related to the majors; career; knowledge; limited understanding of majors, career, university and vocational college; are in issues of resolving conflicts between parents and children when choosing majors, careers; encounter difficulties in making decisions to select suitable majors and careers. As a result of these issues, a half of the surveyed students have not selected the careers and majors. The rest of the students select the majors but most of the choices are not appropriate. On the basis of that results, the study proposes measures and confirms the efficacy of measures on majors, career decison-making of the student.
\end{abstract}

Keywords: issues/difficulties, majors, careers decision making choice, issues in career decision-making process, yourself characteristics, understanding of majors, career, understanding of universities training majors and vocational school, effective measurement

Cite This Article: Truong Thi Hoa, "Common Issues in High School Student's Career Decision - Making Choice and Supporting Measurement in Career Consulting." American Journal of Educational Research, vol. 6, no. 5 (2018): 370-376. doi: 10.12691/education-6-5-1.

\section{Introduction}

Which to choose a career for the future, how to choose which school to study are always difficult questions for each high school students. In the process of making decision for a career, students have many difficulties in self-awareness and self-evaluation, finding information about the majors, training units, the conflict between parents and children in the career making decision choice. If these difficulties are not resolved skippedly, it will cause anxiety for the children and make them making inappropriate decisions in the career choice.

In the countries of the world, Georgia A. Koumoundourou, Kalliopi Kounenou, Eftyxia Siavara (2012), this study explores the intermediary role of self assessment of confidence for career decision- Of 200 high school students in Greece. The authors afirm that for female students, the test results directly and indirectly influence the confidence in making decision for career. For male students, test results only have an indirect effect on selfconfidence in making decision for career [1]. Aaron D. Miller, Patrick J. Rottinghaus (2014) evaluated the relationship between emotional intelligence and conflict patterns in decision-making selection of high school students in Italy [2]. Tirza Willner, Itamar Gatia, Yanjun
Guanb (2015) evaluated the issues of adolescents in career decision-making choice and profile for making career decision in order to help them decide on a better career. This research focuses on the relationship between the career decision questionnaire and the questionnaire on issues in making decision [3]. Dana Vertsberger, Itamar Gati (2016) The study focused on the different supporting forms for adolescents to consider when making career decisions and pointing out the factors that influence searching intemtion of expert's support. The above results also show the diversity of cognitive efficacy among different sources of support (eg, family and friends, career counselors, and the Internet) and their intention to use them. Teenagers tend to seek help from easily accessible resources (such as family and friends, and the Internet), but few seek from proven sources that are truly effective for them (for example career counselors, online tests) [4]. Neslihan BolatHatice Odac (2017), the study pointed out the relationship between career decision and the style of high school final year students. The results show that the effectiveness of career decision making is significantly correlated with safety, fear and attachment styles, and self career decision-making choice in accordance with gender orientation [5]. Lucia Kvitkovičová, Tomotaka Umemuraa, Peter Maceka (2017), this study examines the close-knited relationship of mother, father, best friend and lover in relation to career decision-making process (career information, 
Target and job identification) of high school students. Research finds that the lover is the most influential factor in the career decision-making process of high school students, although the close-knitted relationship with parents and best friends is also important in their career choice [6].

In Vietnam, studies by Pham Thi Ly, Nguyen Thi Kim Lien, Nguyen Trong Tuan, To Hoai Thang, Hoang Huu Dung, Nguyen Nhu Ngoc (2016) mentioned factors influencing students' choice of school decision in some universities in Vietnam include: 1/ Impression of the universities; 2/ Information channel about the universities; 3/ Reasons for choosing that university; 4/ Reasons for students' majors selection [7]. Research by Nguyen Viet Dung, Dang Thi Van (2016), researched the psychological issues in vocational orientation of high school students in Truc Ninh District, Nam Dinh. They pointed out the psychological difficulties that are: the conflict between self career choice and the imposition of parents, between ability and passion, interest [8].

These studies have identified difficulties in the majors, careers decision-making process, and mentioned the important role of the career counselor, but have not yet mentioned specific measures to resolve each kind of difficulties for students in the process of majors and careers selection. This study aims to understand the difficulties of students in majors and career selection and thus propose effective supportive measures in the vocational counseling. The research was conducted by survey (multiple choice) method with 2131 students of 4 upper secondary schools in internal city and 4 upper secondary schools in outskirt areas: Tran Nhan Tong High School - Hai Ba Trung District, Phan Dinh Phung High School - Ba Dinh District, Tran Phu High School, Hoan Kiem District, Nguyen Gia Thieu High School - Long Bien District; Cao Ba Quat High School - Gia Lam District; Ngoc Tao High school - Phuc Tho District; Van Noi high School - Dong Anh District, Phu Xuyen A High School - Phu Xuyen District.

\section{Content}

\subsection{Reality of Majors, Career Selection of High School Students}

The answer to the question "What kind of majors and careers do you choose?" Shows that the proportion of students having choosed careers, majors to work is just over half (51.81\%). In the urban and suburban areas, there is no difference in the results of the selection of majors and careers.

Table 1. Careers and majors of high school students

\begin{tabular}{|c|c|c|c|c|}
\hline \multirow{2}{*}{ Area } & \multicolumn{2}{|c|}{$\begin{array}{r}\text { Non-selection of majors } \\
\text { and career }\end{array}$} & \multicolumn{2}{c|}{$\begin{array}{r}\text { Selection of majors and } \\
\text { career }\end{array}$} \\
\cline { 2 - 5 } & Number & \% (Percent) & Number & \% (Percent) \\
\hline Urban & 529 & 48.62 & 559 & 51.38 \\
\hline Suburban & 504 & 48.32 & 539 & 51.68 \\
\hline Total & 1033 & 48.19 & 1098 & 51.81 \\
\hline
\end{tabular}

(Source: Figures investigated in 2014).

The careers and majors property of $51.81 \%$ of students having selected careers and majors on their capacity, excitement, personality is assessed by the tests: (1) Alfred.W. IQ test. MunZent; (2) John Holland's "Career Competence" Test; (3) A.E.Goller's Career Excitement Tests; (4) MBTI personality test.

In accordance with the results of the multiple choice tests, the students having selected the careers and majors are divided into 4 levels through the criteria:

- Level 1: Selecting the appropriate majors and careers. At this level, students select careers and majors that perfectly matches all of its characteristics such as personality, capacity, excitement.

- Level 2: Choosing the majors and careers that is relatively suitable.Careers and majors students choose are suitable with most of their own characteristics such as fit with capacity, character but less suitable with excitement.

- Level 3: Choosing majors and careers that are less suitable. Careers and majors choose to fit only one part of their own characteristics, such as only fit with excitement and competence; Or just fit your excitement and personality.

- Level 4: Selecting inappropriate majors and careers. Careers and majors students selected are completely inapproriate with their excitement, capacity and character.

Only 3.24\% of surveyed students had selected majors and careers approriate with own personality. Thus, $96.76 \%$ of students need vocational counseling at variable levels.

Table 2. Approriate level between selected careers and majors and personality of own students

\begin{tabular}{|c|c|c|c|c|c|c|c|c|c|c|c|}
\hline \multirow{4}{*}{ Area } & \multirow{4}{*}{ No. } & \multicolumn{10}{|c|}{ Results of student's careers and majors selection assessment } \\
\hline & & \multirow{2}{*}{\multicolumn{2}{|c|}{ Non-selection }} & \multicolumn{8}{|c|}{ Selection } \\
\hline & & & & \multicolumn{2}{|c|}{ Inapproriate } & \multicolumn{2}{|c|}{ Less approriate } & \multicolumn{2}{|c|}{ Relatively approriate } & \multicolumn{2}{|c|}{ Fullly approriate } \\
\hline & & No. & $\%$ & No. & $\%$ & No. & $\%$ & No. & $\%$ & No. & $\%$ \\
\hline Urban area & 1088 & 529 & 48.62 & 227 & 20.86 & 182 & 16.73 & 109 & 10.02 & 41 & 3.77 \\
\hline Suburban area & 1043 & 504 & 46.32 & 215 & 19.76 & 198 & 18.20 & 98 & 9.01 & 28 & 2.57 \\
\hline Total & 2131 & 1033 & 48.47 & 442 & 20.74 & 380 & 17.83 & 207 & 9.71 & 69 & 3.24 \\
\hline
\end{tabular}

(Source: Figures investigated in 2014). 


\subsection{Difficulties in Majors and Careers Selection}

Vocational counseling is only effective when councelor understand common issues that students face in the careers and majors in the careers and majors choice process.

The difficulty is that the majority of students' self-evaluation capacity is still weak. They said that "selfevaluation is limited" (88.17\%). He/she can not answer the question yourself: What is my capacity? What is your personality? What kind of job are you interested in? Students are often confused in evaluating themselves. Thus, $88.96 \%$ of total "don't know whether careers and majors suit him/her" when they are not aware of themselves clearly.

The majority of surveyed students said that they are"lack of knowledge about the careers and majors" (86.02\%). Students only know the careers and majors in general, but not go deep in the detail of careers and majors. Students only know the careers and majors in the one way manner, that is, the high or low salary from that career and line and the location of workplace. Very few students are aware of their occupations in other areas such as requirements, characteristics of majors, careers and demands of the capacity, characteristics, quality of people working in such industries. Almost no students know the social needs of the careers and majors.

Nearly two-thirds of the surveyed respondents are "lack of knowledge of the school" (64.29\%). Knowledge of the school includes a lot of information, but students only know the school about the examination block, conditions for admission, recruitmemt criteria, the entrance mark, the reputation level of the school ... Very few students seek other contents of the school such as learning environment, tuition fees, quality of training majors and careers ...

Causes of lack of knowledge about majors and careers is because students "have difficulties in searching information about the profession" (67.10\%). Some children do not know where to find information. Most students said that the information on the Internet is very different, so students do not know what information is true or false. Is the information guaranteed accuracy, true or false? And when is the information updated? ... Therefore, searching information and information selection and analysis of information on majors and careers is a relatively complex matter that the students himself/herself can not self-settle.

Nearly half of the surveyed respondents said that they " are lack of material related to career guidance" (43.45\%). This is a problem that not only students have encountered, but teachers are also lack of documents, books, information related to the majors and careers, which also greatly affect the choice of students. One student in the suburbs shared, "My school has almost no documentation of career issued for us to refer. On the school library there are only $3 m$ (three) books named educational orientation activities in high school. " Actually, in the book market, students can hardly find many documents on career orientation and career choice. Information about the majors and careers is little, general and lack of up-to-date information.

Majority of students' dificulties in the suburban area is more than in urban areas.

In Vietnam, the family has a great influence on the learning process and prospective decisions of students. Parents who pay for all tuition fee for study and training may sometimes intervene deeply in the process of selecting the majors and careers. This influence is manifested in two aspects: Positive and Negative. Influence is positive when parents are encouraging their children in the process of choosing a line and career, orienting the careers and majors or profession to their children with their understanding ability. Negative impact occurs when parents often ask their children to choose the line or career at the trend of parents, not giving children the right to decide. For example: "There are families with traditional jobs, parents are bank staff and tell the children to follow, but that student is very passionate and capable in the field of art, he wants to follow the artistic path however, his parent definitely does not allow. " More than a half of the surveyed students said he/she "did not resolve the conflict between himself/herself and his/her parents in the choice of majors and careers" (52.98\%). Thus, the particular family factor, that the parent's desire to impose on the children is one of the difficulties in students'choice of majors and careers, leads students to sadness, insecurity for the students.

Table 3. Issues students face in the careers and majors choice process

\begin{tabular}{|c|c|c|c|c|}
\hline \multirow{2}{*}{ Students'issues in the careers and majors choice process } & \multirow{2}{*}{$\begin{array}{c}\text { Urban } \\
\%\end{array}$} & \multirow{2}{*}{$\begin{array}{c}\text { Suburban } \\
\%\end{array}$} & \multicolumn{2}{|c|}{ Total } \\
\hline & & & No. & $\%$ \\
\hline \multicolumn{5}{|l|}{ Issues on self-evaluations } \\
\hline Students don't know whether he/she is appropriate with any majors & 84.19 & 93.38 & 1890 & 88.69 \\
\hline Limited self -evaluation of students & 84.10 & 92.43 & 1879 & 88.17 \\
\hline \multicolumn{5}{|l|}{ Issues on information } \\
\hline Students are lack of careers and majors knowledge & 74.72 & 88.21 & 1833 & 86.02 \\
\hline Students are in trouble with seeking information of careers and majors & 62.41 & 72.00 & 1430 & 67.10 \\
\hline Students are lack of knowlege of training unit & 60.39 & 68.36 & 1370 & 64.29 \\
\hline Lack of knowledge pertaining to career selection & 42.65 & 44.30 & 926 & 43.45 \\
\hline \multicolumn{5}{|l|}{ Issues on conflict with parents } \\
\hline Non-resolved conflict between himself or herself in careers and majors selection & 63.42 & 42.09 & 1129 & 52.98 \\
\hline
\end{tabular}

(Source: Figures investigated in 2014). 
There is a difference in the assessment of the difficult level between students in the urban and the suburban area for students who are not disavantaged in solving the conflict between themselves and their parents in the choice of careers and majors. The proportion of students in this urban area is higher than in the suburban areas. The survey results show that students in the urban area almost have parents who are state officials, even parents who are high executives officials who have many relationships. In contrast, students find that after graduation, they are difficult in seeking work, so they often ask their children to listen to their opinions and be required to study the majors and careers so that his/her parents can easily get jobs for children, students, and not to give the children the freedom to decide. In suburban schools, most of students are children of parents as farmers andf peasants, these parents' understanding of the majors and careers is not much, so they respect their opinions and only expect their children to pass the entrance exam,to enter universities, colleges and have stable jobs and leisured life later. A suburban student said that: "My parents work as farmers, so my social relationships are few, so my parents entirely are supportive of my decision and only want me to enter university to avoid the strenous life of farrmers, and my parent does not make me be under pressure."

\subsection{Supportive Measurements}

In order to assist students in solving difficulties in selecting the careers and majors, the following measures may be applied:

\section{Measurement No. 1: Raise students' awareness and self- evaluation}

The counselor instructs students to recognize and selfevaluate in three aspects: (i) Capacities: impressive competence, strength, aptitude, good subjects; (Ii) Personality, disposition: What kind of person, inward or outward, is in a hot temper; Vivacious; meditative or distressed; (Iii) self-interest: There are special interests.

The counselor helps students assess themselves in four ways:

Method 1: Self-awareness and self-evaluation. The school counselor performs the following tasks:

- Asking questions about himself/herself and answer by himself/herself: What other abilities do I have in comparison with other individuals? What are my hobbies? What is my passion? What is my favorite job? What is my favorite working environment? What do I usually do in my spare time? What do I like to do everyday? How often do you praise me? What is my weakness? ...

- Making list your strengths and weaknesses: List all your strengths, weaknesses in appearance, personality, capacity ...

- Doing multiple choice tests to find out about energy, excitement, personality. Through these tests, students can be self-aware of themselves relatively accurately.

- Comparing self-evaluation results with multiple choice results to confirm self-evaluation results.

- Making a list of all his/her highlights, strengths and weaknesses from the multiple choice results and rubric.

Method 2: Learning yourself through friends, teachers and parents. The counselor instructs the students to talk to their parents, friends and teachers about themselves, through which these students become more aware of themselves.

Method 3: Comparing himself/herself to others. The counselor instructs students to compare themselves with others to find out who is higher or shorter, where they are good and where they are not favorable.

Method 4: Engaging in activities. The counselor advises the students to engage in activities to express themselves, thereby recognizing their strengths, weaknesses and abilities.

After the students learn about themselves, they will identify what they need to replenish what lack, and must train what is weak. In this way, the students perceive and give their initial perception of personality, disposition, energy, excitement.

\section{Measurement No. 2: Improve capcity of seeking information of careers and line for students}

Counselor instructs students: (i) how to find information on careers and majors and occupational requirements, labor market needs of the society; (Ii) evaluation and analysis of the information they find and information provided by the consultant. Through this, students improve their understanding of their majors, occupations, demands, feature of their majors, occupations and labor market needs, and on the economic development of the country and the locality.

Method 1. The consultant helps students to search and evaluate information by the following tasks:

- Consultant exchange with students through open questions to evaluate the choice of information of students when learning about the careers and majors:

Question 1. When exploring these majors and careers, what issues do you usually find out?

Question 2. When exploring these majors and careers, where do you find out about the job?

Question 3. When exploring these majors and career, what difficulties do you find in your career?

- The consultant exchanges, analyzes and helps students identify the gaps in the information they are exploring.

- The counselor gives students the basic contents of the careers and majors guidance they need to learn: (1) qualification and capacities requirements; (2) labor object; (3) purpose of labor; (4) work tools; (5) working conditions; (6) medical contraindications; (7) necessary conditions for apprenticeship; (8) specific work of occupations; (9) future workplace of the profession; (10) Vocational training schools.

- The consultant instructs students how to find information on careers and majors by exploring list of universities, colleges and majors on ministry of education and training, announcing the annual enrollment of the schools on the websites; reading magazines, job postings on newspapers and television; exploring the career world at national and international levels through internet.

Method 2: Instruction for students to participate in organized school activities to increase awareness of the world of work, such as: Writing or eloquence on topics related to career orientation; participating in seminars, exchanges with talented people in the major field, ...

Method 3: Learn information through friends, teachers, parents, relatives. The consultant instructs the students to exchange information with their parents, friends and teachers about the careers and majors information. 
Measurement No. 3: Making improvement for students' capacity of seeking information on training schools

It is not difficult for students to find information about schools, but to find out information about the school in a specific, complete and clear way, you need to know how to do it. This measure aims to improve the capacity of students in the search for information about training schools. To do this, the consultant should do the following.

Method 1. The consultant helps students to search and evaluate information through the following tasks:

- Consultant exchange with students with open questions to evaluate the information choice of students when learning about the school:

Question 1. When you learn explore the school, what issues do you usually find out about?

Question 2. Where do you find out about the school?

Question 3. What are your difficulties when learning about the training schools?

- The consultants and students exchange information and help students to confirm that the information they find themselves are incomplete.

- The consultant orientates information about the school that the student needs to search. The consultant introduces the following contents to the students: (1) how many colleges and universities; (2) Examination groups and Examination/ enrollment conditions; (3) benchmark of the school, careers and majors benchmark of the past years; (4) School targets, majors target; (5) learning environment and conditions; (6) training school location; (7) tuition fees; (8) The quality of the school's training majors ...

- The consultant exchanges and guides the students how to find information on the training schools such as: Searching information via the internet, MOET (Ministry of education and training) websites, universities and colleges; The website provides credible career orientation information: Tuoi Tre, Dan Tri, Thanh Nien; Find information through books, newspapers, career brochures ((enrollment guide, Nhat Nghe Tinh career orientation book "Tu sach huong nghiep nhat nghe tinh", necesssary things about university and college enrollment "Nhung dieu can biet ve tuyen sinh dai hoc" annually published by the MOET, college publications, of the newspaper like Giao duc (education), Tuoi Tre (Youth), Thanh nien (Teenagers) ...)

Method 2: Consultant advises students to visit universities and colleges to see the learning environment and conditions. Learn more about the careers and majors that students are interested.

Method 3: Consultant advises students to find out information about the school through friends, teachers, parents and relatives. The consultant instructs the students to exchange with parents, friends and teachers about the careers and majors training schools.

Measuement No. 4: Formation of capacity of careers, majors selection

Counselors conduct following work:

- Help students determine relationship between capacities and personalty, interest of themselves on careers and lines.

The consultant instructs the students to analyze, compare his personality, abilities, excitement and circumstances with the requirements and characteristics of these career and the needs of the society. Since then, students find a match between the characteristics of themselves and the careers and majors to choose from the needs of society.

In this process, the students analyzes, compares and correlates the characteristics of oneself and the understanding of careers and majors and the labor market of the society. Students compare their own characteristics including capacities, values, interests, personalities and family circumstances with the characteristics, content, tools, working environments of careers, the requirements of the recriutors recruitment, type of work. In the process of comparison, there will be many situations such as: Lines that are appropriate to their personalities but unsuitable with their capacity and proficiency but not suitable for their excitement; careers that fit personality, capacity but inapproriate with labor demand .... Therefore, the consultant must note the students carefully to select the appropriate careers and majors .

To do that, the consultant asked students to do the following:

+ Analyze the psychological characteristics of students personality, personality, excitement, and give their five career options related to psychological characteristics.

+ Analyze the requirements on capacity and qualification of each careers and majors

+ Find a common point between the capacity, personality, interests and requirements of the capacity and qualification of each careers and majors.

+ If students have not yet selected the careers and majors related to their own psychological characteristics, students need to expand the list of careers and majors they are interest in and after that they are considered review what characteristics are the most important in the selection off majors and careers. The result of the analysis is to obtain a list of 5 sectors.

- Assist students in identifying 3 appropriate majors and careers and training schools to be selected

The consultant identifies 3 (three) suitable majors and careers for students: There are many different options based on the combination of diversity of capacity, value, personality and excitement of each individuals. Therefore, students often offer a variety of different approriate options in the majors and careers, training, training in accordance with the capacity, personality and excitement of each child. The consultant should instruct students to narrow their choice of lines of work, by eliminating the choices that are less suited to their competence, personalities and excitement.

To do that, the consultant asked students to do the following:

+ Sort 5 (five) sectors selected in order from the more or less common points with the characteristics themselves.

+ Keep only 3 (three) industries at the top of list.

- Help students find the school they chose.

The counselor's job is to guide the student to find the career training school that he / she has chosen above by comparing his / her capacity with the requirements of the university and college enrollment . The purpose is to help students find suitable schools for enrollment.

To do that, the consultant asked students to do the following:

+ List the schools that have trained the above 3 majors and career; Clarify the contents explored in each school, 
ranking the schools in accordance with the from high to low admission requirements.

+ Analyze students ability and studying capacity;

+ Identify appropriate training schools for each careers and majors.

- Assist the students to analyze, compare the level of compatibility between themselves and the three careers and majors that have been considered and finally make decision on the appropriate majors and careers.

The consultant should discuss with students about the suitability of the job: suitability with career is considered compatibility in the pair "occupation - people"; In particular, it is the correspondence between the characteristics of the psycho-physiological characteristics of individuals and the specific requirements of work in the occupational line for the labor force and the social requirements for the occupation.

From the three options identified above, the consultant instructs the students to carefully analyze each of their strengths and weaknesses to the requirements and characteristics of each branch or profession; Analysis of advantages and disadvantages of each branch; Consider the inadequacies and benefits of each option to yourself and your family members, the social community.

To do that, the consultant asked students to do the following:

+ To carefully examine each careers and majors on the strengths and weaknesses and himself/ herself advantage and disavantage

+ Collating, comparing with labor market needs, family conditions

+ Arrange the occupations along with the training schools in order of priority.

In this way, the students gradually identify themselves and choose the most appropriate careers and majors and training school. When carefully considered, students will confidently make decisions for themselves; The counselor only motivates and affirms their abilities so that students can be confident in making the right choice.

\section{Measurement No. 5: Making improvement for students'} capacity on resolving issues in career choice process

As mentioned above, students have many difficulties in solving issues in the process of choosing a career, especially resolving the conflict between parents and children in the selection of careers and majors. The purpose of this measure is to improve the problem solving ability of students when they encounter difficulties, in particular difficulties in psychology.

The counselor gives orientation for students the following jobs:

+ To identify your own difficulties: Students need to determine exactly what the difficulty is? Sort the order of difficulty.

+ To identify and analyze the causes of such problems. In this context, the counselor assists the student in understanding and analyzing the causes of the problem.

+ To provide solutions according to the reasons students analyzed, the counselor assisted the students in finding solutions. At this time, consultants and students can come up with many options.

+ To analyze the advantages and disadvantages of the options. Based on the options provided, the counselor assists the student to carefully analyze each of the advantages and disadvantages, strengths and weaknesses of each option.

+ To choose the most appropriate solution. The counselor assists students in prioritizing resolution options. Students choose a solution that has more advantages, strength and less disadvantages.

+ To plan the implementation plan. The counselor assists the student in planning the implementation of the resolution plan with specific time and employment. During the implementation and resolution process, the consultant should pay attention, support and supervise in time to help them implement the plan most effectively.

\subsection{The Result of Impact}

In accordance with the results of the multiple choice tests and answers of the students expecting about the field of training during the survey, we classified students according to each problem they encountered.

Can be divided into the following groups of issues:

- Group 1: Insufficient self-awareness and lack of knowledge about the careers and majors, conflict in the careers and majors choice between themselves and the parents; between capacity and interest in choosing a profession; Not know what career choice.

- Group 2: Students have insufficient knowledge about themselves and lack of knowledge about the careers and majors and can not choose or they choose the wrong careers and majors or training school.

- Group 3: Students have a relatively good self-awareness, good knowledge of the careers and majors and full, have chosen the right career but chose the wrong training unit.

- Group 4: Students have good self-evaluation and,good and full understanding of careers and majors, right choice of careers and majors and training schools

According to the results of the multiple choice tests and surveys (Table 2), only $3.24 \%$ of students in group 4 . They chose their own fields and chose the right training schools without impact.

Table 4. Consulting measurement for each group is identified specicially as follow

\begin{tabular}{|c|c|c|c|c|}
\hline Matter group & Measurement No. 1 & Measurement No. 2 & Measurement No. 3 & Measurement No. 4 \\
\hline Group 1 & $\mathrm{x}$ & $\mathrm{x}$ & $\mathrm{x}$ & $\mathrm{x}$ \\
\hline Group 2 & $\mathrm{x}$ & $\mathrm{x}$ & $\mathrm{x}$ & $\mathrm{x}$ \\
\hline Group 3 & $\mathrm{x}$ & $\mathrm{x}$ & $\mathrm{x}$ \\
\hline
\end{tabular}

With these measures, we choose a class of $12^{\text {th }}$ grade at Ngoc Tao high school to impact. The effectiveness of the above measure is shown in the Table 5. 
Table 5. Comparison between careers and majors choice of students before and after impact

\begin{tabular}{|c|c|c|c|c|c|c|c|c|c|c|c|}
\hline \multirow{4}{*}{$\begin{array}{l}\text { The period of } \\
\text { survey }\end{array}$} & \multirow{4}{*}{ No. } & \multicolumn{10}{|c|}{ Evaluation for results of students ' careers and majors choices } \\
\hline & & \multirow{2}{*}{\multicolumn{2}{|c|}{ Non-selection }} & \multicolumn{8}{|c|}{ Selection } \\
\hline & & & & \multicolumn{2}{|c|}{ Inapproriate } & \multicolumn{2}{|c|}{ Less approriate } & \multicolumn{2}{|c|}{ Relative approriate } & \multicolumn{2}{|c|}{ Fully approriate } \\
\hline & & No. & $\%$ & No. & $\%$ & No. & $\%$ & No. & $\%$ & No. & $\%$ \\
\hline Before impact & 45 & 19 & 42.22 & 5 & 11.11 & 19 & 42.22 & 2 & 4.44 & 0 & 0 \\
\hline After impact & 45 & 0 & 0 & 0 & 0 & 0 & 0 & 27 & 60.0 & 18 & 40.0 \\
\hline
\end{tabular}

(Source: Figure investigated in 2014).

\section{Conclusion}

In general, the research results show that students have many difficulties in the process of selecting careers and majors. These difficulties make the majority of students have inapproriate selection of careers and majors. The study has built five impact measures to support solution to the three groups of students after being classified according to the type of difficulty. Each measures has shown that the appropriate operation and impacting results and has confirmed the effectiveness of the measures built.

\section{References}

[1] Georgia A. Koumoundourou, Kalliopi Kounenou, Eftyxia Siavara (2012), Core Self-Evaluations, Career Decision Self-Efficacy, and Vocational Identity Among Greek Adolescents, Journal of Career Development, Volume: 39 issue: 3, page(s): 269-286.

[2] Aaron D. Miller, Patrick J. Rottinghaus (2014), Career Indecision, Meaning in Life, and Anxiety, Journal of Career Development, Vol 22, Issue 2, p. 233-247.

[3] TirzaWillnera, ItamarGatia, YanjunGuanb (2015), Career decision-making profiles and career decision-making difficulties: A cross-cultural comparison among US, Israeli, and Chinese samples, Journal of Vocational Behavior Volume 88 Pages 143-153.
[4] Dana Vertsberger, Itamar Gati (2016), The effectiveness of sources of support in career decision-making: A two-year followup, Journal of Vocational Behavior, Volume 89 Pages 151-161.

[5] Neslihan Bolat Hatice Odac (2017), High School Final Year Students' Career Decision-Making Self-Efficacy, Attachment Styles and Gender Role Orientations, Current Psychology, June 2017, Volume 36, Issue 2, p. 252-259.

[6] Lucia Kvitkovičová, Tomotaka Umemuraa, PetrMaceka (2017), Roles of attachment relationships in emerging adults' career decision-making process: A two-year longitudinal research design, Journal of Vocational Behavior, Volume 101 Pages 119-132.

[7] Pham Thi Ly, Nguyen Thi Kim Lien, Nguyen Trong Tuan, To Hoai Thang, Hoang Huu Dung, Nguyen Nhu Ngoc (2016), Factors affecting students' decision to choose a training unit in some universities in Vietnam, Educational science No. 133, October, Page.1-4.

[8] Nguyen Viet Dung, Dang Thi Van (2016), Psychological difficulties in career orientation of high school students in Truc Ninh District, Nam Dinh, Magazine of social psychologics, No. 09 September (Page.47. 59).

[9] A.E.Golomstock (2002), Psychologic practical tasks, "Psychologic multiple choice and interest, career exploration”, Hanoi national university Press

[10] Alfred. W. Mun Zent (1997), IQ mulotiple choice test, American psychologist.

[11] H.J. Eysenck (2004), Psychological multiple choice, second episode. Multiple choice of personality: "Personality multiple choice and appropriate work for different personalities”, National university of education press. 